\title{
Jakub Spurek*
}

\section{ZATRZYMANIE PRAWA JAZDY DLUŻNIKOWI ALIMENTACYJNEMU A PRYMAT RODZICÓW W WYCHOWANIU DZIECI}

\section{Streszczenie}

Celem artykułu jest próba ustalenia, czy prymat rodziców w wychowaniu dziecka oznacza także pierwszeństwo obowiązków wobec niego, w tym zwłaszcza obowiązków alimentacyjnych. W artykule omówiono jeden z instrumentów prawnych, który ze względu na swą dolegliwość ma na celu zmobilizowanie dłużników do wywiązywania się z ustalonych przez sąd zobowiązań alimentacyjnych. Na tle sporu o konstytucyjność przyjętego rozwiązania przeprowadzono analizę adekwatności zastosowanego środka do celu, który za jego pomocą chce się osiągnąć.

Słowa kluczowe: obowiązek alimentacyjny, fundusz alimentacyjny, zasada proporcjonalności, prawo jazdy, Trybunał Konstytucyjny

\section{Wprowadzenie}

Wychowanie dziecka jest jednym z podstawowych zadań wchodzących w zakres sprawowanej przez rodziców władzy rodzicielskiej. W artykule pod-

* mgr Jakub Spurek, Instytut Nauk Prawnych Polskiej Akademii Nauk, adres e-mail: jakub.spurek@gmail.com, ORCID: 0000-0002-7032-7063. 
jęto próbę ustalenia, czy prymat rodziców w wychowaniu dziecka oznacza także pierwszeństwo obowiązków wobec niego oraz czy obejmuje on także obowiązek dostarczania środków utrzymania.

W dyskusji społecznej ciągle aktualne jest pytanie o efektywność egzekwowania przez państwo realizacji alimentacyjnych obowiązków dłużników. W niniejszym opracowaniu ocenie - z perspektywy skuteczności i proporcjonalności - poddany zostanie jeden ze środków prawnych mający służyć wskazanemu celowi, a mianowicie zatrzymanie prawa jazdy.

\section{Prymat rodziców w wychowaniu dziecka a obowiązki alimentacyjne}

Sytuacja prawna dziecka żyjącego w rodzinie dotkniętej dysfunkcją powinna być oceniana $\mathrm{w}$ świetle realizowania przez rodzinę jej podstawowych funkcji, tj. opiekuńczo-zabezpieczającej, socjalizacyjnej i ekonomicznej ${ }^{1}$. Przez pryzmat wskazanych ról można zaobserwować i ocenić postępowanie rodziców w trakcie wypełniania przez nich ich najważniejszych obowiązków związanych z zaspakajaniem potrzeb ekonomicznych rodziny, sprawowaniem codziennej pieczy nad dzieckiem i wychowaniem go. Obserwacje te dają z kolei mocne podstawy do analizy i oceny prowadzonej przez państwo polityki rodzinnej².

Jedną z konsekwencji tak pojętej roli rodziny jest uznanie prymatu rodziców w wychowaniu dzieci zgodnie ze swoimi przekonaniami, rozumianego jako ogół zabiegów mających na celu ukształtowanie człowieka pod względem fizycznym, moralnym i umysłowym oraz przygotowanie go do życia w społeczeństwie ${ }^{3}$. Pierwszeństwo to przejawia się w wielu aspektach życia i dotyczy chociażby przekazywania określonego światopoglądu czy decydowania o kierunku edukacji dziecka. Reguła ta jest silnie osadzona w porządku prawnym, a za jej filary uznaje się Konwencję o prawach dziecka (art. 7, 8 ust. 1 i 18) ${ }^{4}$, ustawę zasadniczą

1 Na temat funkcji rodziny zob. Z. Tyszka, Struktura i funkcje rodziny oraz świadomość rodzinna, w: Z. Tyszka, A. Wachowiak, Podstawowe pojęcia i zagadnienia socjologii rodziny, Poznań 1997, s. 46-59; Z. Tyszka, Socjologia rodziny, Warszawa 1979, s. 61-69; F. Adamski, Rodzina. Wymiar społeczno-kulturowy, Kraków 2002, s. 36-42; F. Adamski, Socjologia matżeństwa i rodziny. Wprowadzenie, Warszawa 1982, s. 49.

2 M. Andrzejewski, Ochrona praw dziecka w rodzinie dysfunkcyjnej (dziecko - rodzina państwo), Kraków 2003, s. 23-28.

3 Stownik języka polskiego PWN, t. 3, red. M. Szymczak, Warszawa 1978, s. 730.

${ }^{4}$ Konwencja o prawach dziecka (Dz.U. z 1991 r., nr 120, poz. 526) - zwana dalej: k.o p.d. 
(art. 48, a także art. 18, 71 i 72) $)^{5}$ oraz kodeks rodzinny i opiekuńczy (w szczególności art. $95 \S 1,96 \S 1,128,133 \S 1)^{6}$.

Pierwszeństwo oznacza uprawnienie, z którym skorelowany jest obowiązek rodzica wychowania dziecka. Nie wynika on wprost z treści przepisu, jego istnienie wyprowadzić można z:

- łącznego odczytania art. 18, 70 ust. 3, art. 71 oraz 72 ust. 2 Konstytucji RP

- postanowień art. 18 Konwencji o prawach dziecka (,,rodzice ponoszą odpowiedzialność za wychowanie i rozwój dziecka") ${ }^{8}$,

- możliwości pozbawienia lub ograniczenia praw rodzicielskich,

- ustawodawstwa zwykłego doprecyzowującego regulacje konstytucyjną w postaci obowiązku pieczy nad osobą dziecka9

- analizy regulacji tej problematyki w ustawach zasadniczych innych państw, w których dominują zapisy określające wychowanie dziecka jako prawo i obowiązek rodziców ${ }^{10}$.

Granicę uprawnień wychowawczych rodziców stanowi prawo dzieci do korzystania z wolności sumienia i wyznania, a także przekonań, w tym również politycznych i światopoglądowych. Realizacja tego uprawnienia następuje proporcjonalnie do stopnia rozwoju dziecka oraz pod nadzorem. Przy czym ocena stopnia dojrzałości nie jest pozostawiona wyłącznie rodzicom i ustawodawca określa zakres samodzielności decyzyjnej dziecka w różnym wieku (np. w kwestii decydowania o uczestniczeniu w lekcjach religii w szkole $)^{11}$. W przypadku niewłaściwego wykonywania przez rodziców swoich obowiązków rodzicielskich czy też wywierania złego wpływu na proces wychowywania dziecka sąd może ograniczyć lub całkowicie pozbawić ich praw rodzicielskich. Jest to podyktowane dobrem dziecka.

5 Konstytucja Rzeczypospolitej z dnia 2 kwietnia 1997 r. (Dz.U. nr 78, poz. 483).

6 Kodeks rodzinny i opiekuńczy z dnia 25 lutego 1964 r. (Dz.U. z 2017 r., poz. 682 z późn. zm.) - zwany dalej: k.r.o.

7 W. Borysiak, w: Konstytucja RP. Tom I. Komentarz do art. 1-86, red. M. Safjan, L. Bosek, Warszawa 2016, s. 1207.

8 Ibidem.

9 B. Banaszak, Konstytucja Rzeczypospolitej Polskiej. Komentarz, Warszawa 2012, s. 301. $\mathrm{Na}$ temat relacji regulacji ustawodawstwa konstytucyjnego i ustawodawstwa zwykłego zob. wyrok TK z 21 stycznia 2014 r., sygn. SK 5/12, Legalis nr 815910.

10 Zob. art. 30 konstytucji Włoch; art. 6 ust. 2 ustawy zasadniczej Republiki Federalnej Niemiec; art. 54 konstytucji Słowenii. Por. P. Sarnecki, w: Konstytucja Rzeczypospolitej Polskiej. Komentarz. Tom II, red. L. Garlicki, M. Zubik, Warszawa 2016, s. 254.

11 Zob. W. Borysiak, w: Konstytucja RP. Tom I. Komentarz do art. 1-86, s. 1210; wyrok TK z 11 października 2011 r., sygn. K 16/10, SIP LEX nr 992832. 
Powyższe ustalenia prowadzą do wniosku, że pojęcie prymatu rodziców należy rozumieć nie tylko jako pierwszeństwo w wychowaniu dziecka, ale także jako pierwszeństwo w obowiązkach wobec niego. Dobro dziecka jest wartością nadrzędną nad interesami innych osób. Szerokie rozumienie pojęcia sprawia, że zalicza się do niego także ochronę roszczeń alimentacyjnych. Jednym z elementów wychowania jest bowiem troska o prawidłowy intelektualny i fizyczny rozwój dziecka i z niej wynika obowiązek ekonomicznego wspierania dziecka ${ }^{12}$.

Realizując funkcję ekonomiczną, rodzina zmierza do zaspokajania potrzeb swoich członków. Pozyskanie odpowiednich środków (zwykle pieniężnych) spoczywa na rodzicach. Działania te polegają na wykonywaniu pracy najemnej, świadczeniu usług, prowadzeniu gospodarstwa rolnego, pobieraniu świadczeń emerytalnych lub rentowych, a także na codziennych pracach w gospodarstwie domowym, takich jak sprzątanie czy gotowanie ${ }^{13}$. W ramach swoich możliwości zarobkowych i majątkowych rodzice zaspokajają potrzeby dziecka związane $\mathrm{z}$ jego utrzymaniem i wychowaniem.

Każde dziecko ma prawo do życia na poziomie pozwalającym mu na godną egzystencję (postulaty podobnej stopy życiowej oraz odpowiadającej jego rozwojowi fizycznemu, moralnemu, duchowemu i społecznemu, które można wyinterpretować z k.r.o. i k.o p.d.), a realizacja tego zadania spoczywa na członkach grupy rodzinnej. Prawo alimentacyjne w sposób bezwzględnie obowiązujący wskazuje krąg osób uprawionych i zobowiązanych do dostarczania środków utrzymania i wychowania, czyniąc to wedle kryterium rodzinnej bliskości osób zobowiązanych ${ }^{14}$.

Mechanizm ten zbliżony jest do zasady pomocniczości, która określa powinność podmiotu usytuowanego w dalszej kolejności wobec jednostki lub grupy wymagającej wsparcia jedynie wobec niemożności udzielenia go przez

12 Pogląd dominujący. Zob. M. Andrzejewski, Ochrona praw dziecka.., s. 95-163. W. Borysiak, w: Konstytucja RP. Tom I. Komentarz do art. 1-86 s. 1207; B. Banaszak, op. cit., s. 299-300; M. Bartoszewicz, w: Konstytucja Rzeczypospolitej Polskiej. Komentarz, red. M. Haczkowska, Warszawa 2014, s. 76. Podobnie, orzeczenie TK z 12 kwietnia 2011 r., sygn. SK 62/08, Legalis nr 311533, w którym Trybunał Konstytucyjny stwierdził, że obowiązek alimentacyjny jest refleksem wynikającego z art. 48 ust. 1 Konstytucji RP obowiązku współprzyczyniania się rodziców do wychowywania dziecka.

13 Tak M. Andrzejewski, Ochrona praw dziecka..., s. 32; Z. Tyszka, Struktura i funkcje rodziny..., s. 47-48; F. Adamski, Rodzina..., s. 42.

14 M. Andrzejewski, Ochrona praw dziecka..., s. 103-111; T. Smyczyński, Obowiązek alimentacyjny, w: System Prawa Prywatnego, t. 12. Prawo rodzinne i opiekuńcze, red. T. Smyczyński, Warszawa 2014, s. 761-766; Kodeks rodzinny i opiekuńczy. Komentarz, red. K. Pietrzykowski, Warszawa 2018, s. 1002-1011; J. Gwiazdomorski, Przesłanki istnienia obowiazku alimentacyjnego, Warszawa 1974, s. 5-23. 
podmiot usytuowany bliżej ${ }^{15}$. Rolą państwa jest wspomaganie rodzin w realizacji tego zadania przede wszystkim przez wymuszenie odpowiedzialnych względem dziecka zachowań jego rodziców (art. 27 ust. 2 i 3 k.o.p.d., art. 71 Konstytucji RP). Powinność ta zawiera w sobie jednocześnie zakaz zdejmowania z rodziny obowiązków (funkcji), którym nie może sama sprostać (pomaganie, a nie zastępowanie). W niesieniu pomocy ubogim państwo nie powinno wyprzedzać dalszych krewnych tych osób. Efektem wsparcia ma być doprowadzenie adresatów do samodzielności oraz zapewnienie łożenia na utrzymanie dziecka ze strony rodziców lub innych osób ponoszących za nie finansową odpowiedzialność. W świetle regulacji kodeksu rodzinnego i opiekuńczego powinność ta powstaje w przypadku, gdy nie ma osoby zobowiązanej w bliższej kolejności albo gdy osoba ta nie jest w stanie uczynić zadość swemu obowiązkowi lub gdy uzyskanie od niej na czas potrzebnych uprawnionemu środków utrzymania jest niemożliwe lub połączone z nadmiernymi trudnościami (art. 132 k.r.o.). Osoba, która podejmuje się trudu utrzymywania dziecka, uzyskuje prawo do wystąpienia wobec pierwotnie zobowiązanego z roszczeniem zwrotnym (regresowym) ${ }^{16}$.

Powyższe prowadzi do wniosku, że problemy obywateli powinny być rozwiązywane w rodzinie, a następnie przez środowisko, w którym żyją. Rozważenia wymaga rola państwa w procesie niesienia pomocy podmiotom, które jej potrzebują. Wsparcie takie realizowane jest w szczególności poprzez świadczenia socjalne oraz środki z funduszu alimentacyjnego ${ }^{17}$. Jak wspomniano, zapew-

15 M. Andrzejewski, Ochrona praw dziecka..., s. 110, 155. Na temat zasady pomocniczości zob. A. Dylus, Zasada pomocniczości a integracja Europy, „Państwo i Prawo” 1995, nr 5, s 52-58, A. Dylus, Zasada pomocniczości a procesy transformacji, „Polityka Społeczna” 1993, nr 9; S. Golinowska, Polityka społeczna państwa w gospodarce rynkowej. Studium ekonomiczne, Warszawa 1994, s. 172-173; M. Andrzejewski, Pomocnicza rola państwa w świetle Konwencji o Prawach Dziecka i prawa polskiego, w: Współczesne kierunki w opiece nad dzieckiem. Wybór tekstów, red. Z.W. Stelmaszuk, Warszawa 1999, s. 84 i n.

16 W konstrukcji roszczenia regresowego podkreśla się kwestie jego zakresu - dany podmiot może domagać się równowartości tego, co sam zapłacił. Jeśli łożył on wyższe kwoty od należnych alimentów, wówczas nie może od dłużnika żądać zwrotu nadwyżki. Zob. M. Andrzejewski, w: Kodeks rodzinny i opiekuńczy. Komentarz, red. H. Dolecki, T. Sokołowski, Warszawa 2013, s. 891-893.

17 Ustawa z dnia 7 września 2007 r. o pomocy osobom uprawionym uprawnionym do alimentów, tekst jedn. Dz.U. z 2018 r., poz. 554 z późn. zm. Instrumentem pomocy państwa osobom uprawionym do alimentów jest system świadczeń z funduszu alimentacyjnego, nie zaś instytucja prawna „funduszu alimentacyjnego”. Ustawodawca wybierając tytuł aktu prawnego, a także określając jej zakres przedmiotowy, zdecydował się na położenie nacisku na „pomoc państwa”, a nie instytucjonalnym ,funduszu alimentacyjnym”. Na temat regulacji, których celem było publicznoprawne kompensowanie niedoborów w środkach utrzymania rodziny wywołanych niewywiązywaniem się z obowiązku alimentacyjnego, zob. W. Maciejko, Administracyjne środki dyscyplinowania 
nienie bezpieczeństwa ekonomicznego dziecka spoczywa na rodzicach lub osobach odpowiedzialnych za dziecko.

\section{Geneza i specyfika zatrzymania prawa jazdy dłużnikowi alimentacyjnemu}

Dzieci pozbawione środków do życia zmuszone są od skorzystania z pomocy ekonomicznej państwa. Jednym z jej filarów jest fundusz alimentacyjny, który spełnia dwie podstawowe funkcje: socjalną (opieka nad osobami znajdującymi się w trudnej sytuacji materialnej z powodu niemożności wyegzekwowania świadczeń alimentacyjnych) oraz dyscyplinującą (doprowadzenie do zwiększenia odpowiedzialności osób zobowiązanych do alimentacji) ${ }^{18}$. Przyznanie świadczeń z funduszu alimentacyjnego ma na celu czasowe zabezpieczenie uprawionego przed niebezpieczeństwem niemożności zaspokajania usprawiedliwionych bieżących potrzeb. Działanie to musi być rozumiane jako wspieranie, a nie zastępowanie przez państwo rodziców w ich obowiązkach wobec dzieci ${ }^{19}$.

Jednym z instrumentów prawnych, który z uwagi na swoją dolegliwość ma na celu zmobilizowanie dłużników do wywiązywania się z ustalonych przez sąd zobowiązań alimentacyjnych, jest zatrzymanie prawa jazdy. Dotyczy on osób posiadających uprawienie do kierowania pojazdami i polega na czasowym zatrzymaniu dokumentu potwierdzającego posiadania uprawienia do kierowania określonymi pojazdami na terytorium Rzeczypospolitej Polskiej bądź w ruchu międzynarodowym ${ }^{20}$. Środek ten został wprowadzony do polskiego systemu prawnego na podstawie ustawy z dnia 22 kwietnia 2005 roku o postępowaniu

dlużnika alimentacyjnego oraz fundusz alimentacyjny, w: Alimenty. Komentarz, red. J. Ignaczewski, M. Karcz, W. Maciejko, M. Romańska, Warszawa 2014, s. 250-292.

18 Zob. szerzej M. Andrzejewski, Fundusz alimentacyjny. Komentarz do ustawy z dnia 18 lipca 1974 r., Lublin 1995, s. 31-32.

19 Por. uchwałę SN z 16 grudnia 1987 r. w sprawie wytycznych w zakresie wykładni prawa i praktyki sądowej w sprawach o alimenty, teza X, MP 1988, nr 6, poz. 60.

20 Por. art. 5 ust. 1 ustawy z dnia 5 stycznia 2011 r. o kierujących pojazdami (Dz.U. z 2017 r., poz. 978 z późn. zm.). Od niniejszego środka odróżnić należy zakaz prowadzenia pojazdów, o którym mowa w art. 39 pkt 3 k.k. Orzekany jest on wobec osób skazanych za przestępstwa przeciwko bezpieczeństwu w komunikacji. Ten środek karny można orzec niezależnie od tego, czy osoba posiada uprawienia do prowadzenia pojazdów. Na gruncie ustawy o pomocy osobom uprawionym do alimentów organ właściwy dłużnika kieruje wniosek do starosty o zatrzymanie prawa jazdy dłużnikowi alimentacyjnemu po uzyskaniu z centralnej ewidencji kierowców informacji, że posiada on uprawnienie do kierowania pojazdami (por. art. 5 ust. $3 \mathrm{~b}$ pkt 2 ustawy o pomocy osobom uprawnionym do alimentów). 
wobec dłużników alimentacyjnych i zaliczce alimentacyjnej ${ }^{21} \mathrm{z}$ dniem jej wejścia w życie, tj. od 1 czerwca 2005 roku. Przepisy o odbieraniu dłużnikom alimentacyjnym prawa jazdy zawarto w obecnie obowiązującej ustawie o pomocy osobom uprawnionym do alimentów.

Dla przejrzystości dalszego wywodu konieczna jest krótka charakterystyka regulacji ustawowych ${ }^{22}$. Ustawa o postępowaniu wobec dłużników alimentacyjnych i zaliczce alimentacyjnej nakładała na organ właściwy dłużnika obowiązek poinformowania podmiotu uprawnionego do złożenia wniosku o ściganie przestępstwa uporczywej niealimentacji (z art. 209 k.k.), jeżeli ten uniemożliwiał przeprowadzenie wywiadu środowiskowego lub odmawiał podjęcia prób aktywizacji zawodowej. W przypadku przyznania zaliczki alimentacyjnej lub świadczeń rodzinnych ściganie odbywało się z urzędu. Jeżeli powyższy wniosek został złożony, organ właściwy dłużnika obligatoryjnie kierował do starosty wniosek o zatrzymanie prawa jazdy dłużnika alimentacyjnego. Na podstawie tego wniosku starosta musiał wydać decyzję o zatrzymaniu prawa jazdy.

Podobna regulacja obowiązywała do 2011 roku także w ustawie o pomocy osobom uprawnionym do alimentów z tą różnicą, że skierowanie wniosku do starosty o zatrzymanie prawa jazdy nie było związane ze ściganiem przestępstwa uporczywej niealimentacji ${ }^{23}$. Po 2012 roku możliwość zatrzymania prawa jazdy została uzależniona od wcześniejszego przeprowadzenia postępowania administracyjnego o uznanie dłużnika za uchylającego się od zobowiązań alimentacyjnych ${ }^{24}$. Decyzja taka zostaje wydana w przypadku spełnienia określonych w ustawie przesłanek, tj. w sytuacji, gdy dłużnik uniemożliwia przeprowadzenie wywiadu alimentacyjnego, odmawia złożenia oświadczenia majątkowego, bez uzasadnionej przyczyny nie podejmuje pracy lub odmawia zarejestrowania się w powiatowym urzędzie pracy jako bezrobotny albo poszukujący pracy, a także uchyla się od prac interwencyjnych ${ }^{25}$. Decyzji o uznaniu dłużnika alimentacyjnego za uchylającego się od zobowiązań alimentacyj-

21 Dz.U. z 2005 r., nr 86, poz. 732 z późn. zm.

22 Na temat postępowania organów samorządu terytorialnego wobec dłużników alimentacyjnych zob. E. Kidyba, Samorząd terytorialny wobec dlużników alimentacyjnych, „Służba Pracownicza. Miesięcznik Ministerstwa Pracy i Polityki Społecznej”2013, nr 10, s. 24-26.

23 A. Juryk, Działania zmierzające do poprawy wykonywania przez dtużnika obowiązku alimentacyjnego na rzecz dziecka, „Rocznik Administracji Publicznej” 2016, nr 2, s. 41.

24 Ustawa z dnia 19 sierpnia 2011 r. o zmianie ustawy o świadczeniach rodzinnych oraz ustawy o pomocy osobom uprawionym do alimentów (Dz.U. nr 205, poz. 1212).

$25 \mathrm{~W}$ doktrynie określane mianem przesłanek pozytywnych (art. 5 ust. 3 ustawy o pomocy osobom uprawnionym do alimentów). 
nych nie wydaje się wobec dłużnika alimentacyjnego, który przez ostatnich 6 miesięcy wywiązywał się w każdym miesiącu ze zobowiązań alimentacyjnych w kwocie nie niższej niż 50\% kwoty bieżąco ustalonych alimentów ${ }^{26}$.

Okres zatrzymania prawa jazdy uzależniony jest od zachowania się dłużnika. Zgodnie $\mathrm{z}$ aktualnym stanem prawnym uchylenie decyzji następuje w przypadku podjęcia przez niego współpracy z organami władzy publicznej (gdy odpadnie przyczyna z art. 5 ust. 3 ustawy o pomocy osobom uprawnionym do alimentów) oraz w przypadku gdy przez ostatnich 6 miesięcy wywiązał się w każdym miesiącu ze zobowiązań alimentacyjnych w kwocie nie niższej niż 50\% kwoty bieżąco ustalonych alimentów lub nastąpiła utrata statusu dłużnika alimentacyjnego ${ }^{27}$. Postępowanie może nastąpić jedynie na wniosek organu właściwego dłużnika.

\section{Problematyka zatrzymania prawa jazdy dłużnikowi alimentacyjnemu z perspektywy doktryny i orzecznictwa Trybunału Konstytucyjnego}

Zagadnienie możliwości odebrania prawa jazdy dłużnikowi alimentacyjnemu było przedmiotem dwóch orzeczeń Trybunału Konstytucyjnego: z 2009 roku, w którym regulacja ta została uznana za niekonstytucyjną ${ }^{28}$, oraz z 2014 roku - stwierdzającym jej konstytucyjność ${ }^{29}$. Pierwotnie uznano, że środek ten jest niezgodny z konstytucyjną zasadą proporcjonalności z uwagi na nieadekwatność pomiędzy celem regulacji (doprowadzenie do skutecznego wymuszenia na dłużniku obowiązku alimentacyjnego) a przyjętym sposobem (zatrzymanie prawa jazdy). Nadto uznano, że jest on zbyt dolegliwy dla zobowiązanego ${ }^{30}$. Ówczesna

$26 \mathrm{~W}$ doktrynie określana mianem przesłanki negatywnej (art. 5 ust. 3a ustawy o pomocy osobom uprawnionym do alimentów). Zgodnie z dominującym poglądem, aby uznać dłużnika za uchylającego się od zobowiązań alimentacyjnych, konieczne jest spełnienie łącznie przesłanki negatywnej oraz jednej z przesłanek pozytywnych. W judykaturze spotkać można zapatrywanie odmienne, zgodnie z którym przesłanka negatywna może stanowić samodzielną podstawę decyzji. Zob. wyrok WSA w Olsztynie z 4 czerwca 2013 r., sygn. II SA/Ol 387/13, SIP LEX nr 1330727.

27 Na gruncie ustawy o postępowaniu wobec dłużników alimentacyjnych i zaliczce alimentacyjnej zwrot zatrzymanego prawa jazdy następował, gdy dłużnik umożliwił przeprowadzenie wywiadu alimentacyjnego, złożył oświadczenie majątkowe, zarejestrował się jako bezrobotny albo poszukujący pracy, podjął pracę albo inną formę aktywizacji zawodowej zaproponowaną przez powiatowy urząd pracy.

28 Wyrok TK z 22 września 2009 r., sygn. P 46/07, SIP LEX nr 533559.

29 Wyrok TK z 12 lutego 2014 r., sygn. K 23/10, SIP LEX nr 1427299.

30 Orzeczenie wydane zostało na gruncie ówcześnie obowiązującego art. 5 ustawy o postępowaniu wobec dłużników alimentacyjnych i zaliczce alimentacyjnej. Por. M. Andrzejewski, w: 
regulacja uznana została za sprzeczną z zasadą prawidłowej legislacji z uwagi na brak trybu odwoławczego i automatyzm w uwzględnianiu przez starostę wniosku pochodzącego od wójta ${ }^{31}$.

Powyższe rozstrzygnięcie stało się przedmiotem szerokiej dyskusji w doktrynie. Zgłoszony został postulat całkowitej rezygnacji z zatrzymywania prawa jazdy dłużników alimentacyjnych w procedurze alimentacyjnej, wskazując na brak związku między niewywiązywaniem się z obowiązku alimentacyjnego a uprawieniem do kierowania pojazdami ${ }^{32}$. Powoływano ponadto argument, że zatrzymanie prawa jazdy niweczy lub utrudnia dłużnikowi możliwość zarobkowania, a w konsekwencji możliwości wypełniania obowiązków alimentacyjnych ${ }^{33}$. Stwierdzono, że kryterium uznania, że dłużnik wywiązuje się z obowiązku alimentacyjnego jest zbyt rygorystyczne i powinno zostać złagodzone, a przesłanki uznania dłużnika alimentacyjnego za uchylającego się od zobowiązań alimentacyjnych nie pozostawiają organom administracji publicznej tzw. luzu decyzyjnego ${ }^{34}$.

Wyrok Trybunału Konstytucyjnego z 2009 roku spotkał się także z krytyką. Podniesiono, że możliwość odebrania dokumentu prawa jazdy nie pojawia się nagle i w żadnym wypadku nie jest dla zobowiązanego zaskoczeniem - krok ten jest finałem długiej (pod względem liczby posunięć i rozciągnięcia w czasie) sekwencji zdarzeń ${ }^{35}$. Środek ten nie dotknąłby dłużnika, gdyby wypełniał on

Kodeks rodzinny i opiekuńczy..., s. 891-893; E. Tomaszewska, Ustawa o pomocy osobom uprawnionym do alimentów. Komentarz, Warszawa 2014, s. 70-74.

31 Należy podkreślić, że orzeczenie wydane zostało na gruncie art. 5 ustawy o postępowaniu wobec dłużników alimentacyjnych i zaliczce alimentacyjnej, która nie obowiązywała w obrocie prawnym w chwili wydania orzeczenia. Niekonstytucyjne zapisy naruszające m.in. zasadę prawa do sądu i dwuinstancyjności postępowania zostały przez ustawodawcę usunięte przy okazji nowelizacji ustawy o pomocy osobom uprawionym do alimentów, np. postępowanie o uznanie dłużnika alimentacyjnego za osobę uchylającą się od zobowiązań alimentacyjnych jest dwuinstancyjne, a konsekwencją ostateczności zapadłej decyzji jest uruchomienie procedury w sprawie zatrzymania prawa jazdy. Zob. też, W. Maciejko, Zwrot prawa jazdy dlużnikowi alimentacyjnemu, „Służba Pracownicza. Miesięcznik Ministerstwa Pracy i Polityki Społecznej” 2009, nr 12, s. 29-30.

32 D.J. Sosnowska, Alimenty a prawo karne. Praktyka wymiaru sprawiedliwości, Warszawa 2012, s. 89.

33 A. Korcz-Maciejko, A. Brzeźna, Ustawa o pomocy osobom uprawionym do alimentów. Komentarz, Warszawa 2014, s. 75-76. Autorki wskazują, że zatrzymanie prawa jazdy dłużnikowi jest w szczególności niecelowe w sytuacji, gdy czerpie środki utrzymania pochodzące z zarobkowego wykonywania transportu i innych zawodów związanych z prowadzeniem pojazdów.

34 D.J. Sosnowska, op. cit., s. 88-89.

35 M. Andrzejewski, Dyscyplinowanie dlużników alimentacyjnych (rozważania na tle dwóch wyroków dotyczacych odbierania im prawa jazdy), w: Prawo alimentacyjne. Zagadnienia systemowe i proceduralne, red. J.M. Łukasiewicz, I. Ramus, Toruń 2015, s. 186. 
nałożony prawem obowiązek ${ }^{36}$. Sankcja w postaci zatrzymania prawa jazdy jest więc działaniem łagodnym, jeśli zestawić je z przyczyną, czyli uchylaniem się od wykonywania obowiązków alimentacyjnych, tzn. jest to odpowiednia sankcja administracyjna, jeśli chodzi o osoby dopuszczające się skandalu, jakim jest niełożenie alimentów na rzecz uprawnionych ${ }^{37}$.

Stanowisko Trybunału godzi ponadto w prymat przepisów o charakterze materialnym nad procesowymi. Zdaniem Trybunału kwestionowana regulacja naruszała w szczególności zasadę sprawiedliwej procedury przez brak stosownego trybu odwoławczego, co sprawiało, że wniosek organu właściwego dłużnika dotyczący zatrzymania prawa jazdy mógł mieć charakter nie dość weryfikowalny, a wręcz arbitralny ${ }^{38}$. Odnosząc się do stanowiska Trybunału, w literaturze powołano argument, że nadmierny respekt dla zasad prawa formalnego zaprzepaszczałby szanse na zrealizowanie celów stawianych ustawie o postępowaniu wobec dłużników alimentacyjnych i zaliczce alimentacyjnej, a odsunięcie w czasie przekazywania alimentów niweczy sens tego świadczenia ${ }^{39}$. Analizując zagadnienie przez pryzmat teorii prawa, wskazano, że prowadziłoby to do sprzeczności prakseologicznej zasady prawa formalnego niweczyłyby unormowania prawnomaterialne ${ }^{40}$.

Kluczową rolę dla rozstrzygnięcia Trybunału Konstytucyjnego z 2014 roku odegrał sposób postrzegania zasady proporcjonalności oraz zasady demokratycznego państwa prawa przez skład orzekający. Istotnym elementem ostatniej z wymienionych reguł jest adekwatność rozwiązań ustawodawczych do zakładanego celu regulacji ${ }^{41}$. Zakres ingerencji dopuszczalnej dla ochrony ogólnego interesu publicznego powinien wyznaczać każdorazowo postulat proporcjonalności, ponieważ stanowi on istotny komponent zasad składających się na pojęcie demokratycznego państwa prawa ${ }^{42}$. Jednym z najważniejszych założeń ustawy o pomocy osobom

36 E. Tomaszewska, op. cit., s. 70-74.

37 M. Andrzejewski, w: Kodeks rodzinny i opiekuńczy..., s. 891-893.

38 Por. uzasadnienie wyroku TK z 22 września 2009 r., sygn. P 46/07, SIP LEX nr 533559. Trybunał odnosząc się do zasady prawidłowej procedury, zwracał uwagę w szczególności na prawo do sądu, jak i zasadę dwuinstancyjności postępowania.

39 M. Andrzejewski, Dyscyplinowanie dhuzników alimentacyjnych..., s. 185.

40 Ibidem, s. 186. H. Pietrzak, Glosa do wyroku Trybunału Konstytucyjnego z dnia 22 września 2009 r. P 46/07 w sprawie zasadności zatrzymania prawa jazdy dlużnikowi alimentacyjnemu, „Prawo Kanoniczne” 2010, nr 1-2, s. 393. Na temat sprzeczności prakseologicznej zob. Z. Ziembiński, Struktura systemu norm prawnych, w: Z teorii i filozofii prawa Zygmunta Ziembińskiego, red. S. Wronkowska, Warszawa 2007, s. 153 i n.

41 Wyrok TK z 9 lipca 2012 r., sygn. P 8/10, SIP LEX nr 1170273.

42 Wyrok TK z 25 listopada 2003 r., sygn. K 37/02, SIP LEX nr 82400. 
uprawnionym do alimentów jest łączenie wspierania osób uprawnionych do alimentów z działaniami zmierzającymi do zwiększenia odpowiedzialności osób zobowiązanych do alimentacji. Dostrzeżenie, a także rozważenie efektywności przyjętych rozwiązań zaprowadziło Trybunał do wydania korzystnego dla wierzycieli alimentacyjnych orzeczenia. Podkreślenia wymaga, że nie rozprawiał on o proporcjonalności abstrakcyjnie, lecz wydał wyrok na postawie empirycznych informacji na temat funkcjonowania przepisów dotyczących odbierania prawa jazdy (tj. danych opracowanych przez Ministerstwo Pracy i Polityki Społecznej oraz Najwyższą Izbę Kontroli). To doprowadziło do uznania przez Trybunał, że pogląd o braku wpływu tego instrumentu na wzrost skuteczności egzekwowania od dłużników alimentacyjnych należnych kwot jest niewłaściwy ${ }^{43}$.

\section{Zatrzymanie prawa jazdy dłużnikowi alimentacyjnemu w świetle zasady proporcjonalności}

Przyjmuje się, że wymóg proporcjonalności zostaje spełniony, jeżeli wprowadzona regulacja ustawodawcza jest $\mathrm{w}$ stanie doprowadzić do zamierzonych przez nią skutków (zasada przydatności), jest niezbędna dla ochrony interesu publicznego, z którym jest powiązana (zasada konieczności), a także jej efekty pozostają w proporcji do ciężarów nakładanych przez nią na obywatela (zasada proporcjonalności sensu stricto $)^{44}$.

Innymi słowy zasada adekwatności wskazuje na metodę ustalania granic dopuszczalnej ingerencji w sferę praw człowieka. Racjonalny prawodawca wybiera cele służące najpełniejszej realizacji określonego systemu wartości, a następnie dobiera najbardziej adekwatne środki do ich realizacji. Za takie uznaje się te, które są zgodne z przyjętym systemem wartości, a także skuteczne dla urzeczywistnienia pożądanego przez prawodawcę stanu fak-

43 W literaturze zwłaszcza M. Andrzejewski, Dyscyplinowanie dłużników alimentacyjnych..., s. 192-193. Trybunał oparł swoje rozstrzygnięcie na następujących danych: informacji na temat realizacji ustawy o pomocy osobom uprawnionym do alimentów Ministerstwa Rodziny, Pracy i Polityki Społecznej, www.mpips.gov.pl/wsparcie-dla-rodzin-z-dziecmi/fundusz-alimentacyjny/informacje-statystyczne/realizacja-ustawy-o-pomocy-osobom-uprawnionym-do-alimentow (dostęp 10.06.2018) i informacji o wynikach kontroli wywiązywania się organów samorządu terytorialnego z zadań na rzecz pomocy osobom uprawnionym do alimentów Najwyższej Izby Kontroli, www.nik.gov.pl/kontrole/wyniki-kontroli-nik/kontrole,7612.html (dostęp 10.06.2018).

44 Zob. w literaturze: M. Korycka-Zirk, Teorie zasad prawa, a zasada proporcjonalności, Warszawa 2012, s. 192-193, w orzecznictwie: wyrok TK z 26 czerwca 1995 r., sygn. K 11/94, Legalis nr 10252. 
tycznego ${ }^{45}$. Nie jest przy tym konieczne, aby wybór środka miał charakter optymalny, wystarczy, że jest w stanie doprowadzić do zamierzonego celu ${ }^{46}$.

Reguła konieczności określa kryterium wyboru środka działania spośród środków o równej skuteczności i zawiera w sobie dyrektywę doboru rozwiązań możliwie najmniej uciążliwych dla podmiotów, wobec których mają być zastosowane. Stopień inwazyjności powinien być oceniany na podstawie faktów sprawy z uwzględnieniem interesów stron uwikłanych w konflikt. Może zdarzyć się przypadek, że środki najbardziej skuteczne są środkami najbardziej restryktywnymi, a obok nich istnieć będą instrumenty mniej dolegliwe, ale i mniej skuteczne - wydaje się, że w takiej sytuacji należy opowiedzieć się za regulacją gwarantującą przydatność do realizacji założonego celu ${ }^{47}$. Należy mieć na uwadze, że ingerencja państwa w sferę praw człowieka jest dopuszczalna wyłącznie, jeżeli jest podejmowana dla ochrony wartości szczególnie cennych dla społeczeństwa. Zasada proporcjonalności sensu stricto nakazuje rozstrzygnięcie konfliktu wartości w taki sposób, aby została zachowana odpowiednia proporcja między ustanowionymi obciążeniami a celem regulacji.

Intencją twórców ustawy o pomocy osobom uprawnionym do alimentów było z jednej strony możliwe niewielkie wsparcie ze strony państwa, polegające na wypłacaniu świadczeń tylko w przypadkach, w których jest to konieczne, z drugiej zaś skuteczne ściąganie należności funduszu od osób zobowiązanych. Dlatego też ustawa wyposażona została w wiele instrumentów dyscyplinujących dłużnika alimentacyjnego oraz instytucje publiczne, aby egzekucja świadczeń była skuteczna ${ }^{48}$. Zdawano sobie bowiem sprawę, że brak jest jednego uniwersalnego i skutecznego środka, który oddziaływałby na każdego dłużnika alimentacyjnego w równym stopniu. Dopiero bowiem stworzenie systemu takich instrumentów wpłynąć może na pozytywne z punktu widzenia wierzycieli zachowania dłużników ${ }^{49}$.

45 K. Wojtyczek, Granice ingerencji ustawodawczej w sfere praw człowieka w Konstytucji $R P$, Kraków 1999, s. 137-138.

46 M. Korycka-Zirk, op. cit., s. 194, K. Wojtyczek, Zasada proporcjonalności, w: Prawa i wolności obywatela w Konstytucji RP, red. B. Banaszak, A. Preisner, Warszawa 2002, s. 682-683.

$47 \mathrm{~W}$ literaturze wskazuje się, że w takiej sytuacji Trybunał Konstytucyjny powinien unikać stwierdzenia niekonstytucyjności badanej regulacji prawnej. Zob. K. Wojtyczek, Granice ingerencji ustawodawczej..., s. 156-157 i powołana tam literatura.

48 Katalog uregulowań został uporządkowany przez M. Andrzejewskiego. Zob. M. Andrzejewski, w: Kodeks rodzinny i opiekuńczy..., s. 890.

49 M. Andrzejewski, Dyscyplinowanie dlużników alimentacyjnych..., s. 192-193; H. Cioch, Fundusz alimentacyjny, w: Rodzina w prawie, red. A. Dzięga, Z. Jancewicz, P. Telusiewicz, Stalowa Wola 2009, s. 48 i n. 
Oceniając omawiany środek prawny w aspekcie jego przydatności i konieczności, zauważyć należy, że dotyczy szczególnej grupy adresatów: wierzyciela alimentacyjnego, którym jest najczęściej małoletnie dziecko, oraz dłużnika alimentacyjnego, tj. rodzica uchylającego się w sposób naganny i uporczywy od spełniania ciążącego na nim obowiązku. Obowiązku, któremu jest w stanie sprostać, bowiem zasądzona kwota określona została w wyroku w oparciu na kryterium zarobkowych i majątkowych możliwości zobowiązanego wyznaczających przecież górny pułap świadczenia alimentacyjnego (nawet gdyby nie prowadziło do zaspokojenia w pełni wierzyciela). Wskazuje się, że brak alimentów powoduje obniżenie statusu materialnego uprawnionych, generując poczucie deklasacji i upokorzenia, które przybiera szczególnie dokuczliwą postać w przypadku dzieci, które często porównują się z lepiej sytuowanymi rówieśnikami. Jest to więc forma przemocy o charakterze ekonomicznym zasługująca na dezaprobatę etyczną i konsekwentne przeciwdziałanie ${ }^{50}$.

Dobrem, które podlega ochronie, są uzasadnione i usprawiedliwione potrzeby dziecka pozostające niezaspokojone (przesłanka proporcjonalności sensu stricto). Obowiązek dostarczania środków utrzymania i wychowania jest bodaj najdonioślejszą z powinności występujących w relacjach rodzinnych. Stanowi wyraz solidarności rodzinnej i istnieje niezależnie od władzy rodzicielskiej i wykonywania pieczy nad dzieckiem. Wymóg zagwarantowania minimum egzystencji każdemu członkowi rodziny jest silnie zakorzeniony w Konstytucji RP (art. 71 ust. 1 zd. 2) ) $^{51}$.

Zastosowanie instytucji zatrzymania prawa jazdy dłużnikowi alimentacyjnemu wymaga rozważenia w kontekście postulatu konieczności ingerencji. Skuteczność środka ocenić można na podstawie danych opublikowanych przez organy, które w sferze stosunków społecznych dysponują fachową wiedzą. Ministerialne raporty o funkcjonowaniu ustawy o pomocy osobom uprawionym do alimentów wskazują, że skierowanie wniosku o zatrzymanie prawa jazdy doprowadziło do wzrostu ściągalności należności średnio w skali 5,92\%-7,90\% przypadków (samych wniosków wydaje się około 30000 rocznie) $)^{52}$.

50 M. Andrzejewski, Dyscyplinowanie dtużników alimentacyjnych..., s. 170.

51 Zob. wyrok TK z 15 listopada 2005 r., sygn. P 3/05, Legalis nr 71237. Zob. też L. Garlicki, w: Konstytucja Rzeczypospolitej Polskiej. Komentarz. Tom I, red. L. Garlicki, M. Zubik, Warszawa 2016, s. 772-773. Autor wskazuje, że dobro dziecka stanowi samoistną wartość konstytucyjną i w związku z tym powinna być realizowana m.in. przy poszanowaniu podmiotowości i godności dziecka. Na kwestię tę zwraca ponadto uwagę sam Trybunał w uzasadnieniu do komentowanego wyżej orzeczenia. Por. wyrok TK z 12 lutego 2014 r., sygn. K 23/10, SIP LEX nr 1427299.

52 Szerzej na ten temat: informacja na temat realizacji ustawy o pomocy osobom uprawnionym do alimentów Ministerstwa Rodziny, Pracy i Polityki Społecznej www.mpips.gov.pl/ 
W uzasadnieniu wyroku z 2014 roku Trybunał wskazał, że efektywność tego środka prawnego kształtuje się na poziomie $20 \% \mathrm{w}$ grupie osób, wobec których skierowano wniosek o zatrzymanie prawa jazdy, a stosowanie instytucji zatrzymania prawa ma wpływ na wzrostową tendencję poziomu ściągalności należności ${ }^{53}$. W ocenie Trybunału wartość ta, gdy mowa o podmiotach charakteryzujących się cechą konsekwentnej uporczywości w niewykonywaniu kolejnych obowiązków prawnych, ma inny ciężar gatunkowy niż chociażby w grupie osób o przeciętnym poziomie postrzegania prawa ${ }^{54}$. Omawiany instrument prawny ma także prewencyjny charakter. Dolegliwość w postaci czasowego pozbawienia prawa jazdy wzbudza $w$ rodzicu-kierowcy determinację, aby tego dokumentu nie stracić, a w przypadku czasowego zatrzymania, aby go odzyskać.

W świetle poglądu prezentowanego przez orzecznictwo zatrzymanie prawa jazdy narusza zasadę proporcjonalności poprzez ograniczenie możliwości aktywizacji zawodowej dłużnika polegające na ograniczeniu ofert pracy, które można do niego skierować, a tym samym nie służy podstawowemu celowi ustawy, jakim jest zapewnienie skuteczności w egzekwowaniu należności alimentacyjnych ${ }^{55}$. Stanowisko to wydaje się nieuprawione. Ustawa o pomocy osobom uprawnionym do alimentów zawiera katalog działań tylko wobec osób, które z powodu braku zatrudnienia nie wywiązują się ze swoich obowiązków alimentacyjnych, a także odmawiają podjęcia się wskazanych prac zarobkowych bądź też uchylają się od wykonywania wskazanych prac. Mechanizm przewidziany w kwestionowanej regulacji stanowi rodzaj normatywnego zabezpieczenia realizacji obowiązków alimentacyjnych przez uporczywego dłużnika alimentacyjnego ${ }^{56}$.

Zatrzymanie prawa jazdy jest niepieniężnym instrumentem prawnym o charakterze administracyjnym, który ma na celu wymuszenie na dłużniku alimentacyjnym spełniania nałożonego na niego obowiązku alimentacji. Jego zastosowanie jest efektem rozłożonego w czasie procesu niewywiązywania się przez zobowiązanego $\mathrm{z}$ innych powinności przewidzianych przez ustawę o pomocy osobom uprawnionym do alimentów. Oznacza to, że ochrona uprawnionego

wsparcie-dla-rodzin-z-dziecmi/fundusz-alimentacyjny/informacje-statystyczne/realizacja-ustawyo-pomocy-osobom-uprawnionym-do-alimentow (10.06.2018).

53 Tak w uzasadnieniu wyroku TK z 12 lutego 2014 r., sygn. K 23/10, SIP LEX nr 1427299.

54 Ibidem.

55 Wyrok TK z 22 września 2009 r., sygn. P 46/07, SIP LEX nr 533559. Podobnie wyrok WSA w Łodzi z 5 października 2010 r., sygn. III SA/Łd 333/10, Legalis nr 3931482.

56 H. Pietrzak, op. cit., s. 394 i powołana tam literatura; E. Tomaszewska, op. cit., s. 70-74. 
z zastosowaniem rozwiązania mniej uciążliwego nie przyniosła skutku. Nie sposób pominąć, że z jednej strony ustawodawca dysponuje pewnym ograniczonym katalogiem środków o funkcji dyscyplinującej, z drugiej zaś zobowiązany jest do poszukiwania rozwiązań prawnych aktywizujących dłużnika w celu odnalezienia źródeł umożliwiających alimentację jego dziecii ${ }^{57}$.

Jak stwierdził Trybunał Konstytucyjny w wyroku z 2014 roku, alternatywą może być jedynie kara pieniężna zupełnie nieadekwatna w niniejszej sytuacji. $\mathrm{W}$ innych krajach europejskich dyskutuje się o wprowadzeniu zakazu prowadzenia pojazdów jako alternatywy dla kary pozbawienia wolności oraz środka karnego wobec osób, dla których kara grzywny nie stanowi dotkliwej sankcji, a więc rozwiązania o charakterze karnoprawnym (silniejszym w skutkach w stosunku do polskiego instrumentu o charakterze administracyjnoprawnym $)^{58}$.

\section{Podsumowanie}

Rodzicom przysługuje prymat $\mathrm{w}$ wychowaniu dzieci zgodnie $\mathrm{z}$ własnymi przekonaniami, co wiąże się z wieloma obowiązkami, wśród których istotną rolę odgrywa powinność dostarczania środków utrzymania i wychowania. Troska o prawidłowy intelektualny i fizyczny rozwój dziecka stanowi element wychowania i z niej wynika obowiązek ekonomicznego wspierania dziecka. W normalnie funkcjonującej rodzinie zadania te realizowane są przez jej członków (krąg osób zobowiązanych i uprawionych do alimentacji wyznacza kodeks rodzinny i opiekuńczy).

Subsydiarna rola państwa polega na zaspokojeniu bieżących i usprawiedliwionych potrzeb uprawionego (najczęściej małoletniego dziecka) i ma charakter czasowy (trwa do momentu podjęcia stosownych działań przez rodziców). Realizowana jest w szczególności przez system świadczeń z funduszu alimentacyjnego. Tak rozumiane wsparcie nie może prowadzić do zastąpienia rodziny w spełnianiu świadczeń alimentacyjnych, bowiem przeznaczone środki podlegają zwrotowi przez zobowiązanego.

57 W. Borysiak, w: Konstytucja RP..., s. 1207.

58 A. Okońska-Diemer, Instrumenty prawne stużace poprawie efektywności dochodzenia świadczeń alimentacyjnych $w$ prawie niemieckim, austriackim i szwajcarskim, Warszawa 2016, s. $\quad 41$, www.iws.org.pl/pliki/files/IWS_Oko\%C5\%84ska\%20A._Instr.\%20pr.\%20s $\% 20 . \% 20$ popr.\%20efektywn._doch.\%20\%C5\%9Bwiadcze\%20alimentac.\%20w\%20pr.\%20niem.\%2C\%20 austriac.\%20i\%20szwajc.pdf (dostęp 24.06.2018). 
Prawo alimentacyjne określa sposoby wymuszania realizacji roszczeń alimentacyjnych, przewidując m.in. sankcje dla osób uchylających się od wykonywania swych obowiązków alimentacyjnych. Jednym z instrumentów służących realizacji wskazanego celu jest zatrzymanie prawa jazdy dłużnikowi alimentacyjnemu. Stosowany jest wobec szczególnie uporczywych w swym zachowaniu adresatów. Instytucję tę uznać należy za niezbędną, pozostającą w racjonalnej i odpowiedniej proporcji do celów, które określone zostały w ustawie o pomocy osobom uprawnionym do alimentów. Dotyczy bowiem ochrony dobra szczególnego rodzaju - usprawiedliwionych i bieżących potrzeb dziecka, które pozostają niezaspokojone. Oceniając skuteczność zatrzymania prawa jazdy dłużnikowi alimentacyjnemu, należy podkreślić, że jego stosowanie ma wpływ na wzrost poziomu ściągalności należności alimentacyjnych.

\section{Literatura}

Adamski F., Rodzina. Wymiar społeczno-kulturowy, Kraków 2002.

Adamski F., Socjologia malżeństwa i rodziny. Wprowadzenie, Warszawa 1982.

Andrzejewski M., Dyscyplinowanie dhużników alimentacyjnych (rozważania na tle dwóch wyroków dotyczacych odbierania im prawa jazdy), w: Prawo alimentacyjne. Zagadnienia systemowe i proceduralne, red. J.M. Łukasiewicz, I. Ramus, Toruń 2015.

Andrzejewski M., Fundusz alimentacyjny. Komentarz do ustawy z dnia 18 lipca $1974 \mathrm{r}$., Lublin 1995.

Andrzejewski M., Ochrona praw dziecka w rodzinie dysfunkcyjnej (dziecko - rodzina państwo), Kraków 2003.

Andrzejewski M., Pomocnicza rola państwa w świetle Konwencji o Prawach Dziecka i prawa polskiego, w: Wspótczesne kierunki w opiece nad dzieckiem. Wybór tekstów, red. Z.W. Stelmaszuk, Warszawa 1999.

Andrzejewski M., w: Kodeks rodzinny i opiekuńczy. Komentarz, red. H. Dolecki, T. Sokołowski, Warszawa 2013.

Banaszak B., Konstytucja Rzeczypospolitej Polskiej. Komentarz, Warszawa 2012.

Bartoszewicz M., w: Konstytucja Rzeczypospolitej Polskiej. Komentarz, red. M. Haczkowska, Warszawa 2014.

Borysiak W., w: Konstytucja RP. Tom I. Komentarz do art. 1-86, red. M. Safjan, L. Bosek, Warszawa 2016.

Cioch H., Fundusz alimentacyjny, w: Rodzina w prawie, red. A. Dzięga, Z. Jancewicz, P. Telusiewicz, Stalowa Wola 2009. 
Dylus A., Zasada pomocniczości a integracja Europy, „Państwo i Prawo” 1995, nr 5.

Dylus A., Zasada pomocniczości a procesy transformacji, „Polityka Społeczna” 1993, nr 9. Garlicki L., w: Konstytucja Rzeczypospolitej Polskiej. Komentarz. Tom I, red. L. Garlicki, M. Zubik, Warszawa 2016.

Golinowska S., Polityka społeczna państwa w gospodarce rynkowej. Studium ekonomiczne, Warszawa 1994.

Gwiazdomorski J., Przesłanki istnienia obowiązu alimentacyjnego, Warszawa 1974.

Informacja na temat realizacji ustawy o pomocy osobom uprawnionym do alimentów Ministerstwa Rodziny, Pracy i Polityki Społecznej, www.mpips.gov.pl/wsparcie-dla-rodzin-z-dziecmi/fundusz alimentacyjny/informacje-statystyczne/realizacjaustawy-o-pomocy-osobom-uprawnionym-do-alimentow.

Juryk A., Działania zmierzajace do poprawy wykonywania przez dtużnika obowiazku alimentacyjnego na rzecz dziecka, „Rocznik Administracji Publicznej” 2016, nr 2.

Kidyba E., Samorząd terytorialny wobec dłużników alimentacyjnych, „Służba Pracownicza. Miesięcznik Ministerstwa Pracy i Polityki Społecznej” 2013, nr 10.

Kodeks rodzinny i opiekuńczy. Komentarz, red. K. Pietrzykowski, Warszawa 2018.

Korcz-Maciejko A., Brzeźna A., Ustawa o pomocy osobom uprawionym do alimentów. Komentarz, Warszawa 2014.

Korycka-Zirk M., Teorie zasad prawa a zasada proporcjonalności, Warszawa 2012.

Maciejko W., Administracyjne środki dyscyplinowania dtużnika alimentacyjnego oraz fundusz alimentacyjny, w: Alimenty. Komentarz, red. J. Ignaczewski, M. Karcz, W. Maciejko, M. Romańska, Warszawa 2014.

Maciejko W., Zwrot prawa jazdy dtużnikowi alimentacyjnemu, „Służba Pracownicza. Miesięcznik Ministerstwa Pracy i Polityki Społecznej” 2009, nr 12.

Okońska-Diemer A., Instrumenty prawne stużace poprawie efektywności dochodzenia świadczeń alimentacyjnych $w$ prawie niemieckim, austriackim i szwajcarskim, Warszawa 2016, s. 41 www.iws.org.pl/pliki/files/IWS_Oko\%C5\%84ska\%20A. Instr.\%20pr.\%20s\%20.\%20popr.\%20efektywn._doch.\%20\%C5\%9Bwiadcze $\% 20$ alimentac.\%20w\%20pr.\%20niem.\%2C\%20austriac.\%20i\%20szwajc.pdf.

Pietrzak H., Glosa do wyroku Trybunału Konstytucyjnego z dnia 22 września 2009 r. P 46/07 w sprawie zasadności zatrzymania prawa jazdy dtużnikowi alimentacyjnemu, „Prawo Kanoniczne” 2010, nr 1-2.

Sarnecki P., w: Konstytucja Rzeczypospolitej Polskiej. Komentarz. Tom II, red. L. Garlicki, M. Zubik, Warszawa 2016.

Słownik języka polskiego PWN, t. 3, red. M. Szymczak, Warszawa 1978.

T. Smyczyński, Obowiązek alimentacyjny, w: System Prawa Prywatnego, t. 12, Prawo rodzinne i opiekuńcze, red. T. Smyczyński, Warszawa 2014. 
Sosnowska D.J., Alimenty a prawo karne. Praktyka wymiaru sprawiedliwości, Warszawa 2012.

Tomaszewska E., Ustawa o pomocy osobom uprawnionym do alimentów. Komentarz, Warszawa 2014.

Tyszka Z., Socjologia rodziny, Warszawa 1979.

Tyszka Z., Struktura i funkcje rodziny oraz świadomość rodzinna, w: Z. Tyszka, A. Wachowiak, Podstawowe pojęcia i zagadnienia socjologii rodziny, Poznań 1997.

Wojtyczek K., Granice ingerencji ustawodawczej w sferę praw człowieka w Konstytucji $R P$, Kraków 1999.

Wojtyczek K., Zasada proporcjonalności, w: Prawa i wolności obywatela w Konstytucji $R P$, red. B. Banaszak, A. Preisner, Warszawa 2002.

Wyniki kontroli wywiąywania się organów samorządu terytorialnego z zadań na rzecz pomocy osobom uprawnionym do alimentów Najwyższej Izby Kontroli, www.nik. gov.pl/kontrole/wyniki-kontroli-nik/kontrole,7612.html.

Ziembiński Z., Struktura systemu norm prawnych, w: Z teorii i filozofii prawa Zygmunta Ziembińskiego, red. S. Wronkowska, Warszawa 2007.

\section{Akty prawne}

Kodeks rodzinny i opiekuńczy z dnia 25 lutego 1964 r. (Dz.U. z 2017 r., poz. 682 z późn. zm.). Konstytucja Rzeczypospolitej z dnia 2 kwietnia 1997 r. (Dz.U. nr 78, poz. 483).

Konwencja o prawach dziecka (Dz.U. z 1991 r., nr 120, poz. 526).

\section{Orzecznictwo}

Uchwała SN z 16 grudnia 1987 r. w sprawie wytycznych w zakresie wykładni prawa i praktyki sądowej w sprawach o alimenty, Teza X, MP 1988, nr 6, poz. 60.

Wyrok WSA w Łodzi z 5 października 2010 r., sygn. III SA/Łd 333/10, Legalis nr 3931482. Wyrok WSA w Olsztynie z 4 czerwca 2013 r., sygn. II SA/O1 387/13, SIP LEX nr 1330727. Wyrok TK z 25 listopada 2003 r., sygn. K 37/02, SIP LEX nr 82400.

Wyrok TK z 22 września 2009 r., sygn. P 46/07, SIP LEX nr 533559.

Orzeczenie TK z 12 kwietnia 2011 r., sygn. SK 62/08, Legalis nr 311533.

Wyrok TK z 26 czerwca 1995 r., sygn. K 11/94, Legalis nr 10252.

Wyrok TK z 15 listopada 2005 r., sygn. P 3/05, Legalis nr 71237.

Wyrok TK z 9 lipca 2012 r., sygn. P 8/10, SIP LEX nr 1170273.

Wyrok TK z 11 października 2011 r., sygn. K 16/10, SIP LEX nr 992832. 
Wyrok TK z 12 lutego 2014 r., sygn. K 23/10, SIP LEX nr 1427299.

Wyrok TK z 21 stycznia 2014 r., sygn. SK 5/12, Legalis nr 815910.

\title{
RETENTION OF THE MAINTENANCE DEBTOR'S DRIVING LICENSE AND PARENTS' PRIMACY IN BRINGING UP CHILDREN
}

\begin{abstract}
Summary
The aim of the article is an attempt to determine whether the primacy of parents in raising a child also means the priority of duties towards them, in particular maintenance obligations. The article deals with one of the legal instruments, which, due to its ailment, is aimed at mobilizing debtors to comply with maintenance obligations determined by courts. Against the background of the dispute about the constitutionality of the adopted solution, an analysis of the adequacy of the applied measure to the goal that is being sought to achieve it will be carried out.
\end{abstract}

Keywords: maintenance obligation, maintenance fund, the principle of proportionality driving licence, the Constitutional Tribunal 